\title{
MEMAHAMI MAKNA DAN MOTIF MASYARAKAT KOTA PARIAMAN DALAM MENDUKUNG PARIAMAN SMART CITY
}

\section{UNDERSTANDING THE MEANING AND MOTIVES OF THE PEOPLE OF PARIAMAN CITY IN SUPPORTING PARIAMAN SMART CITY}

\author{
Dewi Nila Utami, Elva Ronaning Roem dan Sarmiati \\ Universitas Andalas \\ J1. Situjuh Padang, Jati Baru Kec. Padang Timur Kota Padang \\ Sumatera Barat - 25129 \\ dewi.nilautami@gmail.com
}

Diterima: 09 Mei 2020

Direvisi: 06 Juni 2020

Disetujui: 18 Agustus 2020

\begin{abstract}
The Pariaman City Administration has made various efforts to make Pariaman a city of culture and quality by implementing smart city concept. The success of the implementation of Pariaman Smart City is surely also affected by the role and understanding of the community about the concept of smart city. This study aimed to understand the meaning of smart city by the people of Pariaman City and their motives in supporting Pariaman Smart City. This research used a phenomenological approach. Data was collected from in-depth interviews and observation. The results showed that the people of Pariaman City perceived smart city as the use of information technology, effective bureaucracy, better city management and the use of the internet at work. Community support for implementing smart city came from two motives. The first one was "because motive", which suggested the reason of supporting smart city program due to the success of other regions that had implemented the smart city concept earlier. The second motive was "in order to motive", which represented the desire to make Pariaman City more developed and to gain economic benefits.
\end{abstract}

Keywords: Pariaman Smart City, Meanings, Motives, The People of Pariaman City

\begin{abstract}
ABSTRAK
Pemerintah Kota Pariaman melakukan berbagai upaya untuk menjadikan kotanya berbudaya dan berkualitas melalui penerapan konsep smart city. Keberhasilan implementasi Pariaman Smart City tersebut tentunya juga dipengaruhi oleh peran dan pemahaman masyarakat tentang konsep smart city. Penelitian ini bertujuan untuk memahami makna yang dimiliki masyarakat Kota Pariaman tentang smart city dan motif masyarakat Kota Pariaman dalam mendukung Pariaman Smart City. Penelitian ini menggunakan pendekatan fenomenologi. Teknik pengumpulan data dilakukan melalui wawancara mendalam dan observasi. Hasil penelitian menunjukkan bahwa masyarakat Kota Pariaman memaknai smart city sebagai penggunaan teknologi informasi, efektivitas birokrasi, pengelolaan kota yang lebih baik dan pemanfaatan internet dalam pelaksanaan pekerjaan. Dukungan masyarakat terhadap penerapan smart city berasal dari dua motif. Pertama adalah motif karena, yang menyatakan bahwa alasan masyarakat mendukung program smart city adalah karena keberhasilan daerah-daerah lain yang telah menerapkan konsep smart city terlebih dahulu. Kedua adalah motif tujuan, yakni keinginan menjadikan Kota Pariaman lebih maju dan untuk mendapatkan keuntungan ekonomi.
\end{abstract}

Kata Kunci: Pariaman Smart City, Makna, Motif, Masyarakat Kota Pariaman 


\section{PENDAHULUAN}

Perkembangan teknologi informasi dan komunikasi yang begitu pesat telah menggeser bahkan merubah sebagian tatanan kehidupan bermasyarakat, baik dalam hal ekonomi, sosial, maupun budaya. Perubahan ini juga menghadirkan permasalahan-permasalahan yang cukup kompleks yakni pesatnya pertumbuhan penduduk, kesenjangan ekonomi, perubahan lingkungan, permasalahan kesehatan hingga perubahan tatanan sosial dalam masyarakat. Bagaimanapun juga, semua persoalan ini harus ditangani dengan serius.

Setiap negara maupun pemerintah daerah, termasuk di Indonesia, mencoba menjawab tantangan ini dengan menggunakan berbagai macam cara dan konsep. Salah satu cara yang dilakukan adalah penggunaan konsep smart city atau kota pintar. Smart city merupakan campuran antara proyek pintar dan digital serta berbagai kegiatan berbasis nonteknologi dengan tujuan untuk meningkatkan kualitas hidup di ruang kota (Dameri, 2014). Nijkamp dalam Esabella (2016) juga menambahkan bahwa smart city adalah kota yang mampu menggunakan sumber daya manusia, modal sosial, dan infrastruktur telekomunikasi modern untuk mewujudkan pertumbuhan ekonomi berkelanjutan dan kehidupan yang berkualitas, dengan manajemen sumber daya yang bijaksana melalui pemerintahan berbasis partisipasi masyarakat. Meskipun begitu, konsep smart city dari tahun ke tahun terus mengalami perkembangan di berbagai negara ataupun daerah yang telah menerapkannya. Implementasi program ini disesuaikan dengan keadaan di tiap daerah.

Konsep smart city atau kota pintar ini juga telah mulai diperkenalkan pada tahun
2014 di Kota Pariaman. Pemerintah Kota Pariaman telah melakukan berbagai upaya untuk mewujudkannya. Salah satunya yaitu menjadikan Kota Pariaman sebagai kota yang mengutamakan pelayanan publik dan kota yang berbudaya dan berkualitas. Pemerintah Kota Pariaman menjalin kerja sama dengan Kementerian Komunikasi dan Informatika dan PT Telkom Wilayah Telekomunikasi (Witel) Sumatera Barat dalam penyediaan jaringan internet di seluruh wilayah Kota Pariaman sejak tahun 2015 (covesia.com, 2015). Berdasarkan data awal dari Dinas Kominfo Kota Pariaman, hingga akhir tahun 2019 telah tersedia sekitar $85 \%$ jaringan internet di wilayah Kota Pariaman.

Pemerintah Kota Pariaman juga telah menyediakan sejumlah aplikasi yang ditujukan untuk pemerintahan dan masyarakat Kota Pariaman. Berdasarkan data dari Dinas Komunikasi dan Informatika Kota Pariaman yang tertuang dalam dokumen Master Plan eGovernment Kota Pariaman tahun 2019-2023, Pemerintah Kota Pariaman telah memiliki 97 aplikasi yang dikembangkan untuk memudahkan pekerjaan dan kerja sama, baik antar-Organisasi Perangkat Daerah (OPD) maupun antara OPD dengan masyarakat di Kota Pariaman. Penyediaan aplikasi-aplikasi ini bertujuan untuk mewujudkan proses komunikasi dua arah atau interaksi yang lebih erat dan bersifat dinamis antara pemerintah dengan masyarakat. Penyediaan aplikasiaplikasi ini juga merupakan salah satu bagian dari smart city, yakni termasuk dalam dimensi smart government.

Salah satu contoh aplikasi yang ditujukan kepada masyarakat adalah Sistem Aplikasi Mitigasi Bencana dan Kedaruratan (SAMPAN). Aplikasi

SAMPAN dikembangkan untuk mempersiapkan 
masyarakat dalam kegiatan mitigasi bencana. Melalui aplikasi ini masyarakat dapat melaporkan kejadian-kejadian atau bencana yang ada di daerahnya. Laporan masyarakat tersebut kemudian ditindaklanjuti secara online oleh Badan Penanggulangan Bencana Daerah Kota Pariaman. Tidak hanya itu, jika terjadi gempa bumi yang berpotensi tsunami maka aplikasi SAMPAN tersebut akan memberikan peringatan dan menunjukkan jalur evakuasi terdekat sehingga masyarakat bisa melakukan tindakan antisipasi supaya tidak terimbas bencana tersebut (pariamankota.go.id, 2019).

Penyediaan aplikasi-aplikasi tersebut bertujuan untuk memberikan pelayanan yang efektif dan efisien kepada masyarakat. Hal ini merupakan salah satu kunci dalam penerapan e-government, selain pemberdayaan masyarakat dan peningkatan kinerja pemerintah (Noveriyanto, 2018). Aplikasiaplikasi tersebut memberikan gambaran manfaat penggunaan TIK untuk menghilangkan batasan jarak dan waktu dalam pelayanan publik.

Tidak hanya smart government, Pemerintah Kota Pariaman juga telah melaksanakan dimensi smart city lainnya, seperti smart tourism dan smart living. Kota Pariaman telah membenahi jalan-jalan hingga pelosok kota sehingga menjadi jalur transportasi yang nyaman untuk dilewati. Kota Pariaman juga menciptakan taman-taman yang indah dan spot-spot wisata menarik seperti Taman Anas Malik, ASEAN Youth Park, Gandoriah Bridge, Pulau Angso Duo, Monumen Angkatan Laut, Pantai Kata dan lain sebagainya.

Implementasi smart city yang dilakukan oleh Pemerintah Kota Pariaman tersebut kemudian mendapatkan 10 kategori penghargaan dari 14 kategori yang dinilai oleh Rating Kota Cerdas Indonesia (RKCI) di Jakarta. Penilaian yang dilakukan oleh tim RKCI yang terdiri dari para akademisi ITB dan didukung oleh Asosiasi Pemerintah Kota Seluruh Indonesia (APEKSI), BRI serta Indosat berkaitan dengan efisiensi dan efektivitas kota dengan cara cerdas. Adapun 10 kategori yang didapat oleh Kota Pariaman adalah Rating Kesiapan Pemerintahan Digital (Digital Government Readiness), Rating Keamanan dan Kebencanaan Kota (Safe and Secure City), Rating Kesiapan Infrastruktur (Infrastructure Readiness), Rating Lingkungan Cerdas (Smart Environment), Rating Sosial Cerdas (Smart Social), Rating Ekonomi Cerdas (Smart Economy), Rating Mobilitas Cerdas (Smart Mobility), Rating Kesehatan Cerdas (Smart Health), Rating Ekosistem Kompetitif dan Rating Ekosistem Inovatif.

Keberhasilan implementasi smart city tersebut tentunya juga dipengaruhi oleh peran masyarakat. Tanpa adanya partisipasi masyarakat, maka smart city akan sulit terwujud. Anggini (2016) mengemukakan bahwa dalam menyelenggarakan suatu pemerintahan yang berbasis smart city perlu dilakukan pendekatan top-down dan bottomup. Hasil penelitian Novianti dan Syahid (2017) juga memperlihatkan bahwa kolaborasi antara para pemangku kepentingan, pemanfaatan teknologi yang diimbangi dengan kesiapan SDM, kejelasan fokus dalam implementasi program serta kepemimpinan perlu dilakukan dalam mewujudkan smart city.

Pemerintah Kota Pariaman telah melakukan diseminasi informasi tentang konsep Pariaman Smart City ini dengan menggunakan branding Pariaman Smart City kepada masyarakat dalam berbagai bentuk seperti publikasi, sosialisasi, seminar ataupun 
Focus Group Discussion (FGD). Tidak hanya itu, hampir dalam setiap acara yang dihadiri oleh pimpinan daerah Kota Pariaman, baik walikota maupun wakil walikota, selalu disampaikan sekilas tentang Pariaman Smart City (minangkabaunews.com, 2018). Melalui berbagai kegiatan komunikasi yang dilakukan, baik sosialisasi, pertemuan ataupun pemberitaan oleh Pemerintah Kota Pariaman, diharapkan masyarakat dapat mengetahui tentang keberadaan dan makna Pariaman Smart City.

Berdasarkan penelitian yang dilakukan oleh Nurtyasrini dan Hafiar (2016) juga diketahui bahwa komunikasi akan berhasil apabila pesan yang disampaikan oleh sumber (komunikator) cocok dengan kerangka acuan, yakni paduan pengalaman dan pengertian yang diperoleh penerima (komunikan). Hal ini diperkuat oleh penelitian Khoiriyah dan Handoyo (2015) yang menyatakan bahwa realitas objektif atau pengalaman akan mendorong masyarakat melakukan berbagai tindakan yang dianggapnya baik. Dengan kata lain, sosialisasi akan berhasil jika masyarakat telah memiliki pengalaman dan pemahaman yang benar. Hal ini juga akan mendorong masyarakat untuk melakukan tindakan sosial.

Selain pengalaman dan pemahaman, Schutz (1972) mengemukakan bahwa tindakan sosial yang dilakukan individu juga merupakan makna dan kesadaran yang menuntun pada sebuah realitas dunia yang interpretif. Menurut Kamus Besar Bahasa Indonesia, pengalaman merupakan suatu hal yang pernah dialami, dijalani, dirasai ataupun ditanggung. Sementara itu, pemahaman adalah proses, perbuatan atau cara memahami sesuatu (Salim \& Salim, 1995). Lebih lanjut, Benjamin S. Bloom dalam Suharsimi (2009) menyatakan bahwa pemahaman merupakan kemampuan individu untuk mengerti atau memahami sesuatu setelah sesuatu itu diketahui dan diingat. Kemampuan individu untuk mengerti atau memahami sesuatu dapat terjadi melalui proses komunikasi. Dengan kata lain, pemahaman ini merupakan kemampuan dalam menangkap sebuah makna dalam komunikasi. Adapun Salim \& Salim (1995) mendefinisikan makna sebagai pengertian dasar yang diberikan atau yang ada dalam suatu hal.

$$
\text { Pemaknaan merupakan tingkatan }
$$

tertinggi dari pemahaman yaitu tingkatan ekstrapolasi. Pada tingkatan ini, seseorang mampu membuat estimasi atau prediksi berdasarkan pengertian dan kondisi yang diterangkan dalam ide-ide atau simbol, serta mampu membuat kesimpulan yang dihubungkan dengan implikasi dan konsekuensinya (Sudjana dalam Purwanti, 2012). Pemaknaan terjadi jika terdapat audiens atau orang yang menerima pesan. Schoening dan Anderson dalam Nugraha (2017) mengemukakan bahwa audiens melakukan sebuah proses interpretatif dalam menangkap makna dari sebuah pesan. Audiens yang berbeda akan menangkap makna dari apa yang mereka baca atau lihat dengan cara-cara yang berbeda. Adapun pemahaman makna harus memperhatikan tanda linguistik, yaitu unsur makna dan unsur bunyi (F.R. Palmer dalam Ananda, 2017). Hal ini menyebabkan pemahaman makna komunikator menjadi bagian penting dalam mendorong terjadinya tindakan sosial.

Selain itu, tindakan sosial juga dipengaruhi oleh kesadaran ataupun alasan (motif) individu. Menurut Woodworth dalam Utamidewi (2017), motif dapat diartikan sebagai sebuah dorongan yang dapat atau mudah menyebabkan individu melakukan 
kegiatan-kegiatan tertentu atau berbuat sesuatu guna mencapai tujuan-tujuan tertentu.

Jika masyarakat tidak memiliki makna yang benar tentang konsep smart city, maka masyarakat akan menjadi penghalang dalam implementasi smart city. Oleh karena itu, perlu diketahui dan dipahami makna dan motif masyarakat Kota Pariaman dalam mendukung Pariaman Smart City. Adapun tujuan penelitian ini adalah untuk memahami makna smart city bagi masyarakat Kota Pariaman dan motif yang mendorong mereka untuk mendukung penerapan Pariaman Smart City.

\section{METODOLOGI PENELITIAN}

Penelitian ini menggunakan pendekatan kualitatif. Sebuah penelitian kualitatif dimulai dengan asumsi dan penggunaan kerangka penafsiran/teoritis yang membentuk atau memengaruhi studi tentang permasalahan riset yang terkait makna yang dilekatkan oleh individu atau kelompok pada suatu permasalahan sosial atau manusia (Creswell, 2015). Penelitian ini menggunakan paradigma konstruktif dengan tujuan melihat bagaimana proses manusia memberikan makna terhadap sesuatu yang akhirnya menghasilkan suatu kebenaran, panduan berperilaku dan realita yang dikonstruksikan oleh manusia itu sendiri.

Fenomenologi merupakan strategi yang digunakan dalam penelitian ini. Husserl mengemukakan bahwa fenomenologi adalah ilmu tentang penampakan (fenomena) yang menampakkan diri ke pengalaman subjek. Tidak ada penampakan (fenomena) yang tidak dialami. Husserl juga mengungkapkan bahwa hanya dengan berkonsentrasi pada apa yang tampak dalam pengalaman, maka esensi dapat terumuskan dengan jernih (Adian, 2010). Penggunaan strategi penelitian fenomenologi dalam penelitian ini merupakan upaya untuk mengetahui makna dan motif yang dimiliki masyarakat Kota Pariaman tentang konsep smart city melalui pengalaman-pengalaman yang mereka miliki baik pengalaman sosial maupun komunikasi.

Teknik purposive sampling digunakan dalam menentukan informan yang diwawancarai dalam penelitian ini. Dengan menggunakan teknik purposive sampling, informan ditentukan berdasarkan kriteria yang telah ditetapkan dalam penelitian ini. Adapun kriteria informan dalam penelitian ini adalah: (1) orang yang mengetahui tentang adanya Pariaman Smart City, (2) orang yang memiliki pengalaman komunikasi, baik dengan pemerintah ataupun dengan masyarakat, tentang smart city.

Berdasarkan kriteria, maka diperoleh lima orang informan dalam penelitian ini yaitu: seorang Pegawai Negeri Sipil di Kota Pariaman (informan 1), seorang pemilik usaha kuliner (informan 2), seorang seniman Pariaman (informan 3), seorang pemilik portal berita (informan 4), dan bendahara Komite Nasional Pemuda Indonesia (KNPI) Kota Pariaman (informan 5).

Teknik analisis data dalam penelitian ini adalah teknik analisis data fenomenologi Creswell. Dalam penelitian ini, peneliti mencari daftar pernyataan penting yang berkaitan dengan pengalaman informan tentang smart city, mengelompokkannya menjadi unit makna atau tema dan motif serta menentukan esensi dari pengalaman informan tersebut.

\section{HASIL DAN PEMBAHASAN}

Kota Pariaman melakukan berbagai upaya agar konsep smart city ini dikenal oleh masyarakat Kota Pariaman, salah satunya adalah dengan membuat branding Pariaman 
Smart City. Tidak hanya membuat branding Pariaman Smart City, Pemerintah Kota Pariaman pun telah mengundang berbagai lapisan masyarakat pada beberapa kegiatan yang dilakukan, seperti yang dikemukakan oleh informan berikut ini,

"Ada beberapa kali sih diundang KNPI, ya paling kita di diskusi tertentu memasukkan tentang smart city nya. Trus kalau ada diskusi-diskusi tentang industri 4.0, paling di situ kita diskusinya yang menyangkut tentang smart city" (Informan 5, 12 Januari 2020).

Dari hasil wawancara di atas terlihat bahwa Pemerintah Kota Pariaman mencoba mengedukasi masyarakat tentang konsep smart city ini melalui diskusi-diskusi seperti Focus Group Discussion (FGD). Dalam setiap diskusi yang dilakukan, Pemerintah Kota Pariaman selalu membahas tentang konsep smart city.

Melalui berbagai upaya yang telah dilakukan oleh Pemerintah Kota Pariaman dalam mengimplementasikan Pariaman Smart City, masyarakat Kota Pariaman mulai mengetahui tentang konsep tersebut dan memunculkan makna yang beragam tentang smart city. Pertama, konsep smart city dimaknai sebagai penggunaan teknologi informasi dalam kehidupan sehari-hari, seperti yang dikemukakan oleh informan berikut ini:

"Smart city tu kan kota cerdas. Kota yang menggunakan teknologi informasi, ya kan, dalam sektor kehidupannya. Dan itu sudah terasa di Pariaman. Misalnya sekarang kita lapar di rumah, buka aja aplikasi gojek, pesan makanan. Itu satu. Yang kedua, informasi sebelum keluar beritanya, bisa lebih tahu dulu. Informasi itu saya dapat dari media sosial yang privat, misalnya dari telegram atau WA. Saya kan punya anggota di lapangan. Nanti mereka yang memberitahu. Dari situ saya meeting. Rapat redaksi di WA grup aja. Misalnya mengarahkan wartawan, pergi ke sana, kejar itu. Ya rapat redaksi pindah ke online aja” (Informan 4, 26 Desember 2019).

Informan 4 mengutarakan bahwa salah satu bentuk implementasi smart city yang telah ia rasakan dan terapkan adalah dengan melakukan rapat secara online, tidak dibatasi dengan tatap muka. Selain itu, informan seringkali menggunakan media sosial dalam mengarahkan anggotanya untuk mendapatkan informasi yang kemudian dikemas menjadi sebuah berita.

Informan 4 juga menyadari banyaknya manfaat dari perkembangan teknologi informasi. Pengalamannya inilah yang membuat ia memaknai konsep smart city sebagai sebuah kota yang menggunakan teknologi informasi dalam seluruh sektor kehidupan. Pada kenyataannya, penggunaan teknologi informasi merupakan salah satu komponen utama dalam mewujudkan smart city.

Kedua, konsep smart city dimaknai sebagai sebuah efektivitas dan efisiensi dalam penyediaan layanan publik yang dapat meminimalkan proses birokrasi berjenjang seperti diutarakan informan berikut:

"Jadi dengan smart city, dengan perkembangan teknologi informasi, gap, jarak antara pemerintah dengan masyarakatnya sangat tipis. Contoh, misalnya ada hal-hal yang harus diketahui, kalau dulu berjenjang, melapor dulu ke kepala desa, di kepala desa kadang tidak sampai ke meja 
walikota. Kalau sekarang, cukup difoto saja, diberi caption, setelah itu ditautkan atau mention ke akun pribadi walikota atau ke Instagram-nya atau ke Facebook-nya. Itu sudah bisa direspons langsung oleh walikota. Walikota kan tinggal perintah saja” (Informan 4, 26 Desember 2019).

Berdasarkan transkrip wawancara tersebut dapat diketahui bahwa kemajuan teknologi informasi dan komunikasi seperti saat sekarang ini telah memutus birokrasi panjang yang harus dilalui seorang warga dalam menyampaikan keluhannya kepada seorang kepala daerah. Masyarakat cukup melaporkan pengaduan melalui aplikasi ataupun media sosial yang terkoneksi ke media sosial walikota, seperti WhatsApp, Instagram dan Facebook. Dengan demikian, walikota dengan cepat dapat melihat dan memerintahkan dinas terkait untuk segera merespons laporan tersebut. Dalam hal ini, batasan antara seorang warga dengan seorang kepala daerah sudah mulai berkurang. Hal ini senada dengan hasil penelitian yang dilakukan oleh Putra dan Febrina (2019) yang menyatakan bahwa adanya gangguan dan keterbatasan teknologi di masa lampau memaksa manusia mencari solusi atas permasalahan yang ada.

Ketiga, smart city dimaknai sebagai sebuah bentuk pengelolaan kota yang lebih baik. Makna ini dikemukakan oleh informan 3 berikut:

"Semenjak adanya smart city ini, dalam

3 (tiga) tahun terakhir ini, sepanjang pantai ini sudah berubah. Kita bisa melihat, dari ujung ke ujung, semuanya sudah menjadi tempat wisata. Kemana pun pergi bisa menjadi tempat yang bagus untuk berfoto. Kalau dulu, orang berkumpul di Pantai Gandoriah saja. Sekarang sudah benar-benar berubah. Kalau dulu pohon pinus aja semuanya. Kini sudah bersih, sudah jadi tempat wisata. Dulu WC terpanjang kata orang di sini” (Informan 3, 18 Januari 2020).

Perubahan yang terjadi di Kota Pariaman, khususnya di sektor pariwisata telah sangat dirasakan oleh sebagian besar masyarakat di Kota Pariaman. Adanya pengelolaan kota yang lebih baik, terutama kawasan wisata, telah meningkatkan jumlah kunjungan wisatawan, baik domestik maupun mancanegara, ke Kota Pariaman. Berdasarkan data dari BPS Kota Pariaman (2020), hingga akhir tahun 2019 terjadi peningkatan yang cukup signifikan dalam jumlah kunjungan wisatawan ke Kota Pariaman. Pada tahun 2019 tercatat sebanyak 3.925.344 wisatawan yang datang ke Kota Pariaman. Jumlah ini menunjukkan peningkatan dari tahun sebelumnya yang mencatatkan jumlah wisatawan sebanyak 3.320.825 orang.

Keempat, konsep smart city dimaknai sebagai pemanfaatan internet dalam pelaksanaan pekerjaan, seperti yang dikemukakan oleh informan 2 berikut ini:

"Smart city itu, semua aspek itu melakukan kreativitas dan semua aspek juga melakukan pekerjaannya dengan gampang dan itu dibantu oleh internet" (Informan 2, 18 Januari 2020).

Berdasarkan transkrip wawancara tersebut dapat diketahui bahwa masyarakat mengartikan smart city sebagai pemanfaatan internet dalam pelaksanaan pekerjaan. Pekerjaan yang dilaksanakan dengan bantuan internet akan menjadi lebih mudah. Masyarakat juga memanfaatkan internet untuk mempermudah pekerjaan mereka, salah satunya adalah mempromosikan usahanya 
melalui media sosial seperti yang dikemukakan oleh informan berikut,

"Saya punya kedai, satu kedai di pinggir

pantai. Jadi media promosi yang kita

pakai itu memang Instagram dalam

mempromosikan jenis makanan, jenis

kegiatan di sana atau apa pun"

(Informan 2, 18 Januari 2020).

Masyarakat menggunakan media sosial yang mereka miliki untuk mempromosikan apa pun yang mereka kerjakan, termasuk usaha yang sedang mereka tekuni. Media sosial merupakan salah satu cara yang dinilai cukup ampuh untuk memperkenalkan usaha yang sedang ditekuni kepada orang lain. Hal ini dikarenakan media sosial dapat diakses oleh siapa saja, kapan saja dan dimana saja. Dengan mem-posting sesuatu yang baru, aneh ataupun menarik, akan mencuri perhatian orang terhadap informasi tersebut. Hal ini sesuai dengan yang dikemukakan oleh Hermawan dalam Pamungkas dan Zuhroh (2016) bahwa dengan internet pemasaran produk dapat lebih terbantu karena internet memungkinkan proses pemasaran yang lebih efektif, respons yang lebih cepat serta biaya yang lebih murah.

Makna-makna yang dikemukakan oleh masyarakat Kota Pariaman tentang konsep smart city tersebut didasarkan pada pengalaman yang mereka miliki ataupun pengalaman individu-individu lainnya dan interaksi yang terjadi di antara mereka. Hasil penelitian ini senada dengan penelitian yang dilakukan oleh Khoiriyah dan Handoyo (2015) bahwa tindakan yang dilakukan orang sekitar akan memengaruhi seorang individu dalam mengambil tindakan. Pengalaman individu dan lingkungan masa lalu yang menjadikan masyarakat mampu mengambil nilai-nilai atau menyimpulkan suatu pemaknaan, serta sosialisasi di lingkungan keluarga dan lingkungan sekitar akan memengaruhi seorang individu untuk membentuk pemaknaan subjektif. Keempat makna yang dimiliki oleh masyarakat Kota Pariaman tentang konsep smart city dapat digambarkan sebagai berikut,

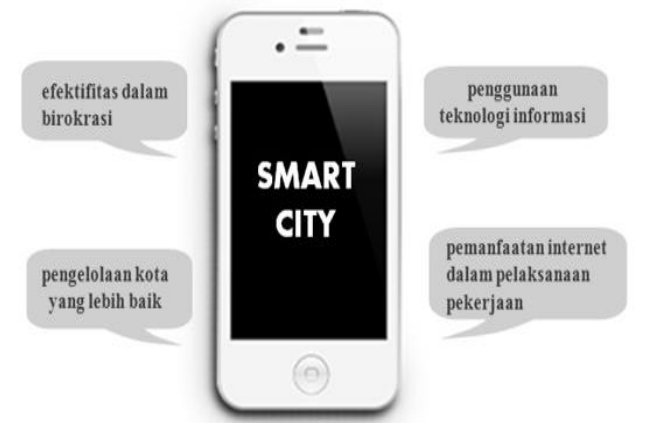

Gambar 1. Makna Smart City oleh Masyarakat Kota Pariaman

Ragam makna yang dikemukakan masyarakat tersebut merupakan bagian kecil dalam pembentukan smart city. Semua penggunaan teknologi dan makna yang ditemukan tersebut mulai mengarah kepada konsep smart city meskipun belum mencakup seluruh makna seperti yang dikemukakan oleh Giffinger. Menurut Giffinger (2007), smart city adalah kota yang berkinerja baik dengan cara pandang ke depan dalam enam karakteristik, yakni pemerintahan, perekonomian, sumber daya manusia, mobilitas, lingkungan, dan kehidupan masyarakat, yang dibangun di atas kombinasi "pintar" dari sumbangan dan kegiatan warga yang dapat menentukan dirinya sendiri, mandiri dan sadar.

Masyarakat Kota Pariaman belum mengetahui ataupun memahami konsep smart city tersebut secara utuh. Mereka hanya mengetahui konsep smart city melalui beberapa dimensi yang mendukung terwujudnya smart city tersebut. Bagaimanapun juga, smart city harus dipahami secara utuh dalam setiap dimensi yang 
mendukung terwujudnya smart city tersebut, tidak hanya oleh pemerintah namun juga oleh masyarakatnya. Beragam makna dan kesadaran masyarakat mengenai konsep smart city serta pengalaman masa lampau akan menuntun mereka menemukan motif untuk melakukan tindakan-tindakan sosial (Kuswarno, 2009)

Berdasarkan hasil wawancara dengan informan dan reduksi data yang dilakukan, peneliti mendapatkan tiga motif yang mendorong masyarakat untuk mendukung penerapan Pariaman Smart city. Ketiga motif yang didapatkan dibagi ke dalam dua kelompok, yaitu because motive (motif karena) dan in order to motive (motif tujuan) seperti yang dikemukakan oleh Schutz (1972) dalam bukunya The Phenomenology of the Social World. Adapun motif karena (because motive) yang melatarbelakangi dan menjadi alasan masyarakat dalam mendukung penerapan konsep smart city di Kota Pariaman adalah keberhasilan daerah-daerah lain yang telah menerapkan konsep smart city. Hal ini sesuai dengan yang dikemukakan oleh informan berikut ini:

"Kenapa kota-kota lain bisa, Semarang bisa, Surabaya bisa, Pariaman kenapa tidak bisa. Apalagi dengan luas daerahnya yang tidak terlalu besar gitu” (Informan 1, 23 Desember 2019).

Berdasarkan hasil wawancara tersebut dapat diketahui bahwa kesuksesan daerah lain menjadi motif alasan (because motive) yang mendorong masyarakat untuk mendukung penerapan smart city di Kota Pariaman. Keberhasilan daerah lain dalam penerapan smart city juga seharusnya dapat diikuti oleh Kota Pariaman. Informan mencoba membandingkan antara Kota Pariaman dengan Kota Semarang dan Surabaya. Kota Surabaya terbilang berhasil dalam menerapkan konsep smart city karena mampu mendorong tumbuhnya partisipasi masyarakat dengan memanfaatkan media sosial dan perkembangan teknologi, informasi dan komunikasi. Hal ini mengakibatkan munculnya suatu hubungan yang kuat dan saling memberikan kontribusi antara masyarakat dan pemerintah sesuai dengan perannya masing-masing. Dengan hal ini, Kota Surabaya telah menggabungkan pendekatan top-down dan bottom-up dalam menyelenggarakan pemerintahan berbasis smart city (Anggini, 2016). Selain Kota Surabaya, masyarakat Kota Pariaman juga menjadikan Kota Semarang sebagai acuan dalam penerapan konsep smart city di Kota Pariaman.

Hasil penelitian Satrio dkk. (2019) menyatakan bahwa Kota Semarang mengalami peningkatan pertumbuhan Indeks Pembangunan Manusia (IPM) yang cukup signifikan sejak tahun 2013 hingga 2018 yakni sebesar 7,62. Komponen tertinggi pembentuk karakter ini dibangun dari aspek smart society, yang telah mendorong percepatan interaksi masyarakat sehingga membentuk pertumbuhan ekonomi yang cukup tinggi. Di Kota Pariaman sendiri telah terlihat adanya interaksi masyarakat. Berdasarkan data dari Dinas Kominfo Kota Pariaman bahwa sejak disosialisasikannya aplikasi LAPOR di Kota Pariaman pada tahun 2019 hingga Juni 2020, telah ada sebanyak 100 laporan, baik dalam bentuk pengaduan, keluhan ataupun saran dari masyarakat untuk kemajuan Kota Pariaman.

Selain motif alasan (because motive), tujuan yang ingin dicapai juga menjadi motif masyarakat untuk mendukung penerapan konsep smart city di Kota Pariaman. Terdapat dua motif tujuan (in order to motive) yang 
melatarbelakangi masyarakat dalam mendukung konsep smart city ini. Motif pertama yaitu keinginan menjadikan Kota Pariaman menjadi lebih berkembang dan maju. Hal ini sesuai dengan hasil wawancara berikut:

"Iya, supaya kota ini lebih berkembang dan maju. Oleh karena itu, makanya harus ada smart city. Sebelumnya, kota ini bisa dibilang tidak berkembang" (Informan 2, 18 Januari 2020).

Hasil wawancara tersebut menunjukkan bahwa informan menyadari bahwa implementasi smart city dapat mendukung Kota Pariaman menjadi sebuah kota yang maju dan berkembang. Pemahaman yang baik tentang smart city akan membantu masyarakat menemukan motif tujuan untuk mendukung implementasi smart city di Kota Pariaman. Dalam hal ini, informan mengemukakan motif berupa manfaat dengan adanya implementasi smart city di Kota Pariaman.

Motif kedua yaitu keinginan untuk mendapatkan keuntungan ekonomi. Hal ini sesuai dengan yang dikemukakan oleh informan berikut ini:

"Apabila daerah kita ramai, hal itu akan
menguntungkan bagi kita. Smart city,
masyarakat dengan rasa kecintaannya,
rasa memiliki daerahnya yang tinggi
secara tidak langsung akan
mempercepat terjadinya smart city
tersebut. Artinya, apabila konsep smart
city itu berkembang, yang akan
diuntungkan adalah masyarakat itu
sendiri, sektor ekonominya, segala
macamnyalah." (Informan $4, \quad 26$
Desember 2019).

Berdasarkan transkrip wawancara tersebut dapat diketahui bahwa informan menyadari tentang manfaat smart city bagi peningkatan perekonomian masyarakat di daerah tersebut. Penerapan konsep smart city diharapkan akan menjadikan Kota Pariaman lebih maju dan banyak dikunjungi wisatawan. Jika Kota Pariaman ramai maka akan memberikan keuntungan bagi masyarakat Kota Pariaman itu sendiri. Kecintaan masyarakat terhadap daerahnya menuntun mereka untuk melakukan tindakan-tindakan sosial yang mempercepat terwujudnya smart city.

\section{KESIMPULAN DAN SARAN}

Berdasarkan hasil penelitian dapat ditarik kesimpulan, pertama: masyarakat Kota Pariaman memaknai konsep smart city sebagai penggunaan teknologi informasi dalam kehidupan sehari-hari, efektivitas dalam birokrasi, pengelolaan kota yang lebih baik, serta pemanfaatan internet dalam pelaksanaan pekerjaan. Kedua, ada tiga motif yang mendorong masyarakat Kota Pariaman untuk mendukung penerapan Pariaman Smart City yang dikelompokkan ke dalam motif karena (because motive) dan motif tujuan (in order to motive). Keberhasilan daerah-daerah lain yang telah menerapkan konsep smart city menjadi motif karena (because motive) yang mendasari masyarakat dalam mendukung penerapan konsep smart city. Adapun motif tujuan (in order to motive) yang dimiliki oleh masyarakat Kota Pariaman untuk mendukung penerapan Pariaman Smart City adalah keinginan menjadikan Kota Pariaman menjadi lebih berkembang dan maju serta keinginan untuk mendapatkan keuntungan ekonomi.

Pemerintah Kota Pariaman disarankan untuk lebih mengedukasi masyarakat tentang smart city dengan menjelaskan secara lebih mendalam tentang enam dimensi yang menunjang terwujudnya smart city tersebut, yakni smart government, smart living, smart economy, smart people, smart tourism, dan 
smart mobility. Keenam dimensi ini tidak dapat dipisahkan dalam rangka mewujudkan smart city. Tidak hanya pemerintah, dukungan yang kuat dari masyarakat akan membantu terwujudnya smart city tersebut.

Dukungan akan muncul jika terdapat pemahaman yang sama antara pemerintah dengan masyarakat tentang konsep smart city yang diusung oleh Pemerintah Kota Pariaman. Masyarakat seharusnya juga lebih aktif dalam mencari tahu dan memahami tentang konsep smart city yang sebenarnya. Dengan adanya sinergi dari semua pihak ditunjang dengan fasilitas-fasilitas dan program-program yang terus dikembangkan, perlahan tapi pasti Kota Pariaman akan bisa terus berkembang menuju impian menjadi smart city secara utuh dalam jangka waktu yang cepat ke depannya.

\section{UCAPAN TERIMA KASIH}

Penelitian ini dibiayai oleh Direktorat Riset dan Pengabdian Masyarakat Deputi Bidang Penguatan Riset dan Pengembangan Kementerian Riset dan Teknologi/Badan Riset dan Inovasi Nasional sesuai dengan Kontrak Penelitian Nomor: 034/SP2H/LT/DRPM/2020 Tahun Anggaran 2020.

\section{DAFTAR PUSTAKA}

Adian, D. G. (2010). Pengantar Fenomenologi. (cet.1). Depok: Koekoesan.

Ananda, R. A. (2017). Pemaknaan Pesan Video Sketsa Pada Instagram @ Alfysaga Di Kalangan Video Creator Sebagai Bentuk Fenomena Kehidupan Anak Muda. Malang: Universitas Muhammadiyah Malang.

Anggini, T., \& Rachmawati, R. (2016). Pemanfaatan Media Center dalam Pelayanan Publik Sebagai Upaya Mewujudkan Surabaya Smart city. Jurnal
Bumi Indonesia. Vol.5 No.1 Tahun 2016, hlm 439-448.

BPS Kota Pariaman. (2020). Kota Pariaman Dalam Angka 2020. Kota Pariaman: BPS

Covesia.com. (2015). Menuju Smart City, Pemko Pariaman Jalin Kerjasama dengan PT. Telkom. Diakses pada 7 Agustus 2019. https://covesia.com/travel/baca/14940/m enuju-smart-city-kota-pariaman-jalinkerjasama-dengan-pt-telkomsel

Creswell, J. W. (2015). Penelitian Kualitatif dan Penelitian Riset: Memilih di antara Lima Pendekatan (ed. 3). (Ahmad Lintang Lazuardi, Trans). Yogyakarta: Pustaka Pelajar.

Dameri, R. P. (2014). Comparing Smart and Digital City: Initiatives and Strategies in Amsterdam and Genoa. Are They Digital and/or Smart?. Dalam R.P. Dameri (Ed.). Smart city: How to Create Public and economic Value with High Technology in Urban Space (h. 45-88). Switzerland: Springer International Publishing.

Dewi, M. \& Nulul, N. A. (2018). Komunikasi Partisipatif Masyarakat Industri dalam Mendukung Brandinging Kota Madiun. Jurnal Ilmu Komunikasi Vol. 15, Nomor 1, Juni 2018, hlm 75-90.

Esabella, S. 2016. Menuju Konsep Smart City. Diakses pada 7 Februari 2019. https://www.researchgate.net/publication /322303099_Menuju_Konsep_Smart_Ci ty

Giffinger, R. (2007). Smart Cities: Ranking of European Medium-Sized Cities. Centre of Regional Science SRF: Vienna University of Technology. $<$ http://www.smart- 
cities.eu/download/smart_cities_final_re port.pdf>

Khoiriyah, N., \& Handoyo, P. (2015).

Konstruksi Sosial Masyarakat Desa Medang Tentang Makam Boyopatih. Jurnal Paradigma, Vol 3, Nomor 2 tahun 2015, hlm 1-8.

Kuswarno, E. (2009). Metodologi Penelitian Komunikasi, Fenomenologi: Konsepsi, Pedoman dan Contoh Penelitian. Bandung: Widya Padjajaran.

Minangkabaunews.com. (2018). Genius Umar Paparkan Smart City Pada Semnas Alumni STAR. Diakses pada 22 Januari 2019.

https://minangkabaunews.com/artikel-

17885-genius-umar-paparkan-smart-

city-pada-semnas-alumni-star.html

Noveriyanto, B., dkk. (2018). E-Government Sebagai Layanan Komunikasi Pemerintah Kota Surabaya. Profetik Jurnal Komunikasi Vol. 11, Nomor 1, April 2018, hlm 37-53.

Novianti, K., \& Syahid, C. (2017). Menuju Kota Cerdas: Pelajaran Dari Konsep Smart city Yang Diterapkan di Jakarta dan Surabaya. Diakses pada 8 Januari 2019.

<https://www.researchgate.net/publicati on/312173841_MENUJU_KOTA_CER

DAS_Pelajaran_dari_Konsep_Smart_Cit y_yang_Diterapkan_di_Jakarta_dan_Sur abaya>

Nugraha, A. (2017). Resepsi Khalayak Mengenai Pemberitaan Rizieq Shihab Terkait Chat Konten Pornografi Di Instagram. Semarang: Universitas Diponegoro.

Nurtyasrini, S., \& Hafiar, H. (2016). Pengalaman Komunikasi Pemulung Tentang Pemeliharaan Kesehatan Diri dan Lingkungan di TPA Bantar Gebang. Jurnal Kajian Komunikasi, Vol 4, No 2, Desember 2016, hlm 219-228.

Pamungkas, B. A., \& Zuhroh, S. (2016). Pengaruh Promosi di Media Sosial dan Word Of Mouth Terhadap Keputusan Pembelian: Studi Kasus Pada Kedai Botancos, Jombang. Jurnal Komunikasi, Vol. X, No.02, September 2016, hlm 145-159.

Pariamankota.go.id. (2019). Kominfo Kota

Pariaman Luncurkan Aplikasi Baru. Diakses pada 5 Mei 2020. https://pariamankota.go.id/berita/kominf o-kota-pariaman-luncurkan-4-aplikasibaru

Purwanti, Indah. (2012). Studi Kasus Tentang Pemahaman Orang Tua Yang Memiliki Anak Berkebutuhan Khusus di SDN Kembangan Kecamatan Kebomas Kabupaten Gresik. Malang: UIN Maulana Malik Ibrahim.

Putra, A. M., \& Febrina, A. (2019). Fenomena Selebgram Anak: Memahami Motif Orang Tua. Jurnal ASPIKOM, Vol. 3, No. 6, Januari 2019, hlm 1093-1108.

Salim, P. \& Salim, Y. (1995). Kamus Bahasa Indonesia Kontemporer. Jakarta: Modern English Press.

Satrio, E. M., \& Rochani, A. (2019). Jurnal Pondasi. Vol 24, No 2 Tahun 2019, hlm 134-147.

Schutz, Alfred. (1972). The Phenomenology of The Social World. Amerika: Northwestern University Press.

Utamidewi, W., dkk. (2017). Pengalaman Komunikasi Keluarga Pada Mantan Buruh Migran Perempuan. Jurnal Kajian Komunikasi, Vol 5, Nomor 1, Juni 2017 , hlm 69-80. 